\title{
Effect of Storytelling on Dental Hygiene Among Prechoolers in Kindergarten
}

\author{
$1^{\text {st }}$ Nuniek Tri W \\ Nursing Departement \\ Sekolah Tinggi Ilmu Kesehatan \\ Cirebon \\ Cirebon, Indonesia \\ nuniek.triwahyuni@yahoo.com \\ $4^{\text {th }}$ Sri Lestari \\ Nursing Departement \\ Sekolah Tinggi Ilmu Kesehatan \\ Cirebon \\ Cirebon, Indonesia
}

\author{
$2^{\text {nd }}$ Supriatin \\ Nursing Departement \\ Sekolah Tinggi Ilmu Kesehatan \\ Cirebon \\ Cirebon, Indonesia
}

\author{
$5^{\text {th }}$ Endang $\mathrm{S}$ \\ Nursing Departement \\ Sekolah Tinggi Ilmu Kesehatan \\ Cirebon \\ Cirebon, Indonesia
}

\author{
$3^{\text {rd }}$ Uun Kurniasih \\ Nursing Departement \\ Sekolah Tinggi Ilmu Kesehatan \\ Cirebon \\ Cirebon, Indonesia
}

\author{
$6^{\text {th }}$ Siti B \\ Nursing Departement \\ Sekolah Tinggi Ilmu Kesehatan \\ Cirebon \\ Cirebon, Indonesia
}

\begin{abstract}
Oral health is an inseparable part of health of other organ systems (systemic health). Limited or inadequate dental care causes the most common problems of all health problems in childhood; those are, tooth decay (dental caries), malocclusion, and periodontal disease. Trauma, especially tooth loss, is also an important problem. (10) According to World Health Organization (WHO) data from the 2016 Global Burden of Disease Study it was estimated that oral disease affected at least 3.58 billion people worldwide. Based on the results of Basic Health Research, there was an increase in the proportion of dental and mouth problems in Indonesia from 2013 to 2018, from a value of $25.9 \%$ to $57.8 \%$. Meanwhile, the proportion of daily tooth brushing behavior in the population at the age of $\geq 3$ years was $94.7 \%$ and the proper behavior of tooth brushing at the age of $\geq 3$ years was $2.8 \%$. This was a quasiexperimental study with one group pre-posttest design. Sampling used total sampling technique with a total sample of 24 respondents. The study instrument used was a dental hygiene observation sheet. Analysis of the data used here was Shapiro-Wilk test. Data analysis used Wilcoxon Signed Rank Test statistical test. The results of this study among Preschoolers Kindergarten, before storytelling showed that 24 children $(100 \%)$ were categorized to have poor dental hygiene. Whereas the results of the study after storytelling showed that 16 children $(66.7 \%)$ were categorized to have good dental hygiene. Data obtained from the Wilcoxon Signed Ranks Test showed a probability value (p-value) of $0.00(\alpha=0.05)$. Thus, it can be concluded that there was an effect of storytelling on dental hygiene among preschoolers Kindergarten. Storytelling is an effective communication tool for preschoolers, so it is strongly recommended for parents to do storytelling to provide motivation and information.
\end{abstract}

Keywords-Storytelling, Dental Hygiene, Prechoolers Kindergarten

\section{INTRODUCTION}

Oral health is an inseparable part of health of other organ systems (systemic health). The tooth layer is composed of enamel, dentin, pulp, and periapical tissue layers, and there are nerve fibers and blood vessels in the pulp tissue that can spread germs or bacteria to other body organ systems. However, until now oral health is still not a major concern. As a result, tooth decay or dental caries becomes a common problem faced by most people. One of the causes of oral health problems in the community is a behavioral factor or attitude that ignores oral hygiene. This is due to the lack of knowledge on the importance of oral health maintenance.(1)

Based on the results of Basic Health Research, there was an increase in the proportion of dental and mouth problems in Indonesia from 2013 to 2018 , from a value of $25.9 \%$ to $57.8 \%$. Meanwhile, the proportion of daily tooth brushing behavior in the population at the age of $\geq$ 3 years was $94.7 \%$ and the proper behavior of tooth brushing at the age of $\geq 3$ years was $2.8 \%$.(2)(3) Likewise the percentage of Effective Medical Demand (EMD) increased at the children age group and the higher age group, and the highest percentage of EMD was found in the 5-9 years age group of $11.7 \%$ and in the 45-54 years age group of $12.8 \%$. Everyone needs to maintain healthy teeth and mouth by brushing their teeth properly to prevent dental caries. The majority (97.0\%) of West Java residents aged 10 years and over had a habit of brushing their teeth every day. (2)

Some of the efforts that have been made by parents to motivate children to maintain dental hygiene are by doing tooth brushing together in the morning and evening before going to bed. They also teach children to brush their teeth by singing, listening to songs, giving gifts after brushing their teeth and choosing a toothbrush and toothpaste as they wish without compromising safety for the child's health. Preschoolers are often interested to play and forget to maintain their personal hygiene and also reluctant to brushing their teeth. Children also tend to get bored easily. Thus, in addition to use lecture in providing dental health education to children, it is necessary to use other methods such as simulation or audio-visual methods so that children may not bored.

The role of pediatric nurses is to provide direct nursing care to children and their families, become an advocate, educator, and manager. In their role as 
educators, nurses provide information and counseling to children and their families about the aspects of health and illness. Pediatric nurses should ensure that communication with children and families is based on the child's age and developmental level. Pediatric nurses should establish evidence-based practice, regulate the provision of care in a cost-effective way to increase continuity of care and optimal outcomes for children and families. (3)

Some methods that are often used in health education include: lectures, group discussions, role plays, demonstrations. (4) Another method that can be used is storytelling. Storytelling has a close relationship with the world of children. It cannot even be denied that fairy tales have their own charm that cannot be rejected by children. Storytelling is an activity that has constructive potential to support mental development of the children, besides that children's thinking will be better, more critical and smarter. Children can also understand which things need to be imitated and which shouldn't be imitated.(5)

Through storytelling, the child's sense of sight and hearing will receive a stimulus in the form of audio excitement, namely the dialogue of characters in the story that contains information about personal hygiene and visual stimulus in the form of puppets as the embodiment of the characters or pictures in the storybook. Audio visual stimulation is transmitted to the child's brain and triggers the production of dopamine in dopaminergic axons in the midbrain. Dopamine is then released from vesicles to deliver messages to other nerve cells.(6)

The results of a study conducted by Listuayu at Mandala Kumara Kindergarten Denpasar, it was shown that there was an effect of giving storytelling on motivation to implement personal hygiene among preschoolers.(5) This is in line with the result of a study conducted by Aries Abiyoga which stated that there was an effect of health education using storytelling method on personal hygiene education about nail hygiene among school-age children in class 1 of MI Darul Azhar Tanah Bumbu.(7) However, a study on dental hygiene using storytelling has not ever been conducted. Thus, the researchers tried to use storytelling to promote dental hygiene among preschoolers.
Based on the results of a preliminary study by interview with the principal of Sabilul Huda Kindergarten, Plered Subdistrict, Cirebon District, it was known that there had never been conducted a study on storytelling of dental hygiene at Sabilul Huda Kindergarten. Sabilul Huda Kindergarten had a total of 34 students. Through interview with 10 Sabilul Huda Kindergarten students, 2 said that they brushed their teeth in the morning and night, 5 students only brushed their teeth in the morning and 3 students rarely brushed their teeth. The reason stated by the 3 students who rarely brushed their teeth was that they were reluctant to do it, and they all said that they liked sweet food. This study was also conducted among respondents who had no problems with dental hygiene.

Based on study that has been done, it was found that dental hygiene before storytelling among preschoolers Kindergarten, showed that 24 people $(100 \%)$ were included in the category of poor dental hygiene maintenance.

\section{METHODS}

The design of this study used a one group pretestprotest design that was an experimental design conducted with pretest before the treatment and posttest after the teratment, without a comparison group. The populations in this study were preschoolers Kindergarten, as many as 24 children. The samples in this study were all populations or total sampling as many as 24 students. Total sampling is the sampling technique based on the total population. (8)

\section{RESULTS}

TABLE 1. DENTAL HYGIENE AMONG PRESCHOOLERS BEFORE STORYTELLING

\begin{tabular}{|c|l|r|r|r|r|}
\hline \multicolumn{2}{|c|}{} & Frequency & Percentage & $\begin{array}{c}\text { Valid } \\
\text { Percentage }\end{array}$ & $\begin{array}{c}\text { Cumulative } \\
\text { Percentage }\end{array}$ \\
\hline \multirow{3}{*}{ Valid } & Good & 0 & 0 & 0 & 0 \\
\cline { 2 - 6 } & Moderate & 0 & 0 & 0 & 0 \\
\cline { 2 - 6 } & Poor & 24 & 100.0 & 100.0 & 100.0 \\
\cline { 2 - 6 } & Total & 24 & 100.0 & 100.0 & \\
\hline
\end{tabular}

Based on table 1 regarding dental hygiene among preschoolers Kindergarten, before storytelling, it can be seen that 24 children $(100 \%)$ experienced problems regarding maintaining dental hygiene.

TABLE 2. DENTAL HYGIENE AMONG PRESCHOOLERS AFTER STORYTELLING

\begin{tabular}{|c|c|c|c|c|c|}
\hline \multicolumn{2}{|c|}{} & Frequency & Percentage & $\begin{array}{c}\text { Valid } \\
\text { Percentage }\end{array}$ & $\begin{array}{c}\text { Cumulative } \\
\text { Percentage }\end{array}$ \\
\hline \multirow{4}{*}{ Valid } & Good & 16 & 66.7 & 66.7 & 66.7 \\
\cline { 2 - 6 } & Moderate & 8 & 33.3 & 33.3 & 100.0 \\
\cline { 2 - 6 } & Poor & 0 & 0 & 0 & 0 \\
\cline { 2 - 6 } & Total & 24 & 100.0 & 100.0 & \\
\hline
\end{tabular}

Based on table 2 regarding dental hygiene among preschoolers Kindergarten, after storytelling, it can be seen that 16 children $(66.7 \%)$ were categorized to have good dental hygiene.
TABLE 3. RESULTS OF DATA NORMALITY TEST ON DENTAL HYGIENE AMONG PRESCHOOLERS BEFORE AND AFTER STORYTELLING

\begin{tabular}{cccccc}
\hline No & Variabel & Statistic & DF & Sign & Conclusion \\
\hline 1. & Pretest & .735 & 24 & 0.000 & Not Normal \\
2. & Posttest & .901 & 24 & 0.023 & Not Normal \\
\hline
\end{tabular}


The results of the data normality test showed that pre-test data obtained a p-value of 0.000 and posttest data obtained a p-value of 0.023 . If it was decided to take the probability value ( $p$-value) of lower than 0.05 , then the two groups of data were not normally distributed. Based

\begin{tabular}{|c|c|c|c|c|c|}
\hline & & $\mathrm{N}$ & Mean Rank & Sum of Ranks & Sig. (2-tailed) \\
\hline \multirow{4}{*}{$\begin{array}{l}\text { Pretest - } \\
\text { Posttest }\end{array}$} & Negative Ranks & $0^{\mathrm{a}}$ & .00 & .00 & 0.000 \\
\hline & Positive Ranks & $24^{\mathrm{b}}$ & 12.50 & 300.00 & \\
\hline & Ties & $0^{c}$ & & & \\
\hline & Total & 24 & & & \\
\hline
\end{tabular}

The calculation result using Wilcoxon Signed Rank Test in Table 4 showed a value of -4.304 with a significance (Asymp. Sig. (2-tailed)) of 0.000 which was lower than the critical limit of the study of 0.05 . Based on the p-value, it can be concluded that $\mathrm{H} 0$ was rejected, meaning that there was a difference in dental hygiene before and after storytelling. The result of the statistical test showed that there was a significant effect of storytelling on dental hygiene among preschoolers Kindergarten.

\section{DISCUSSION}

\section{A. Dental Hygiene before Storytelling}

The result of the study among Preschoolers Kindergarten, before storytelling showed that 24 children $(100 \%)$ were categorized to have poor dental hygiene Lack of dental hygiene can cause various effects such as the occurrence of tooth decay, dental caries, dental plaque, periodontal disease and can even affect the health of other systemic organs. Lack of dental hygiene can also indirectly affect children's intelligence due to dental health problems, a decrease in appetite will result in unbalanced nutritional intake for the growth of the body and brain, namely the intake of protein, carbohydrates, fats, and other nutrients. There are several factors that can affect dental hygiene: age, sex, physical and mental development, dental disease history, psychological condition and personality of the child, type of care, attitude and the performance of the doctor, and the practice environment. Factors that cannot be denied are the attitudes and parenting patterns, these factors are very influential on children's behavior and attitudes.

Attitudes, parenting and knowledge of parents are very influential on personal hygiene including dental hygiene, ranging from tooth tbrushing behavior.

Some of the efforts that have been made by parents to motivate children to maintain dental hygiene are by doing tooth brushing together in the morning and evening before going to bed. They also teach children to brush their teeth by singing, listening to songs, giving gifts after brushing their teeth. Thus, children are not reluctant to brush their teeth regularly. Parents can provide an attractive toothbrush, for example favorite cartoon characters, singers or superheroes and choose toothpaste that has a sweet taste. To encoutage the children to carry out routine checks to the doctor, it is recommended that the treatment or examination is made as attractive as possible using decorations preferred by children so as not to cause a scary atmosphere. Avoiding on the results of data normality test, the hypothesis testing technique used in this study was Wilcoxon signed rank test. cariogenic foods is no less important, so it is suggested that parents can think creatively to prepare a healthy food menu so that children become interested.

\section{B. Dental Hygiene after Storytelling}

Study data on dental hygiene among preschool children Kindergarten, after storytelling showed that 16 children $(66.7 \%)$ had good personal hygiene and 8 children $(33.3 \%)$ had moderate dental hygiene. When compared with dental hygiene before storytelling, it seemed that there was a significant change in dental hygiene after storytelling.

From the data above it was shown that storytelling was an effective communication media to convey information. In the implementation of storytelling, the storyteller must be able to choose the right story material, which should be related to the theme to be taken. In doing storytelling, the storyteller also need to master and memorize the contents of the story. In addition, the storyteller must understand the contents of the story to be told. By carrying out the procedure well, the delivery of storytelling information will benefit, for example, can increase motivation, help the formation of personal and good morals, increase children's imagination and fantasy, and stimulate interest in reading. When the child has provided a two-way response in the implementation of storytelling and starts to imagine what is being told, then the information has been conveyed properly, so that it will increase motivation to maintain dental hygiene. In doing storytelling, it is also necessary to include reasons of why maintaining dental hygiene is very important, and the impact if a child doestn't maintain dental hygiene.

Based on the description that has been explained above, the researchers can assume that change in dental hygiene among preschool children Kindergarten was quite significant. During the implemention of storytelling, it is necessary to approach respondents, and the practitioner must choose a different and interesting story at each meeting so that respondents may not bored.

C. Effect of Storytelling on Dental Hygiene among Preschoolers Kindergarten

The hypothesis test used the Wilcoxon Signed Ranks Test because the data were not normally distributed. The data obtained from the Wilcoxon Signed Ranks Test obtained a probability value (p-value) of 0.014 so that the test conclusion was that there was an effect of storytelling on changes in Dental Hygiene among Preschoolers Kindergarten. 
Storytelling has a close relationship with the world of children. It cannot even be denied that fairy tales have their own charm that cannot be rejected by children. Storytelling is an activity that has constructive potential to support mental development of the children, besides that children's thinking will be better, more critical and smarter. Children can also understand which things need to be imitated and which shouldn't be imitated.(9) According to Colon in Afifah, storytelling is an interesting method for children since children like the attractive shape and colors of images. The advantage of storytelling is that it can teach children to listen, help, develop oral and written communication skills, and develop fluency, increase vocabulary and help improve words. In addition, through storytelling children become interested in asking questions when they do not understand the contents of the story.(10)

Through storytelling, the child's sense of sight and hearing will receive a stimulus in the form of audio excitement, namely the dialogue of characters in the story that contains information about personal hygiene and visual stimulus in the form of puppets as the embodiment of the characters or pictures in the storybook. Audio visual stimulation is transmitted to the child's brain and triggers the production of dopamine in dopaminergic axons in the midbrain. Dopamine is then released from vesicles to deliver messages to other nerve cells.(6) Based on the results of existing study, researchers argued that there was an effect of storytelling on dental hygiene. This is supported by the effect of storytelling which helps in increasing motivation and information on dental hygiene among preschoolers. Storytellers must have good public speaking skills, understand story content and be able to imitate voices, and have clear intonation. Furthermore, storytelling needs to be developed using other teaching aids so that children may not bored.

Based on the description above, it can be seen that there was a strong reason why storytelling was the most effective method that could influence the preschoolers Kindergarten, to increase motivation in maintaining dental hygiene. Storytelling is one approach of many that can make it more likely that someone will take action. It can happen face-to-face, through books, videos, audio, comics and any of the other myriad ways people communicate with each other. When you combine different media, and tell stories from alternate points of view, it gets even more interesting. (11)

\section{CONCLUSIONS}

The pretest result of the study among Preschoolers Kindergarten, before storytelling showed that 24 children $(100 \%)$ were categorized to have poor dental hygiene. The posttest result of the study among Preschoolers Kindergarten, after storytelling showed that 16 children $(66.7 \%)$ were categorized to have good dental hygiene. There was an effect of storytelling on dental hygiene among Preschoolers Kindergarten, with a p-value of 0.014 .

\section{REFERENCES}

[1] Nismal H. Islam and Dental health. Achmad Zirzis, editor Jakarta: Pustaka Al-Kautsar; 2018. 228 p.

[2] Depkes. Health Profile of Wst Java Provincial Health Office [Internet]. www.depkes.co.id. 2016. Available from: www..depkes.co.id/resource/download/profil/PROFIL KES PROVINSI

[3] Kyle T and S. Pediatric Nursing Text. Estu Tiar, sari Isnaini B bariid, editor. Jakarta: EGC; 2014. 32 p.

[4] Sari S arum N. Effect of Health Education on Tooth Brushing Using Simulation Methode with Bass Modification Technique on Skill and Oral Hygiene among the 5th Grade students of Mi At-Taufiq. 2016;

[5] Debora. Nursing Text Book. 6th ed. Jakarta; 2011.

[6] Listiayu. Effect of Story telling on the Motivation to Perform Personal Hygiene among School age Children at Mandala Kumara Kindergarten Denpasar. 2012;

[7] Abiyoga. Effect of Health Education about Personal hygiene using strory Telling Method on Nail Higiene among School Age children. 2018;4.1:8-71.

[8] Aziz A. Nursing Research methods and Data Analysis Technique. Jakarta: Salemba Medika; 2014.

[9] Afifah AM. Effect of Methode story Telling on Tooth Brushing Behaviour among the 4th and 5th Grade Students of Banyuripan kindergarten bangunjiwo kasihan Bantul. 2017;

[10] Astoeti TE. Total Quality Management in Dental Health Education in Schools. Jakarta; 2019.

[11] Prabhakararao Sampathirao. Storytelling as a Method of Health Education. J Indian Psychol [Internet]. 2016;3(2). Available from: http://www.ijip.in 